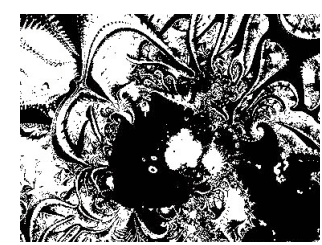

\title{
ADOLESCENT APPRAISALS OF FAMILY SECURITY AS A MEDIATOR OF THE EFFECT OF FAMILY INSTABILITY ON ADOLESCENT SELF-ESTEEM
}

Marina MERKAŠ

Institute of Social Sciences Ivo Pilar, Zagreb

UDK 159.922.8:316.356.2

Izvorni znanstveni rad

Primljeno: 11. 3. 2013.

Author's Note The data presented in this paper are collected as a part of a comprehensive study on adolescent family relations and social competence. I am very grateful to all the children, parents and school staff who invested their time and effort to participate in the project.
The aim of this two-wave study was to examine the mediating role of adolescent appraisals of family security in the relation between family instability and adolescent self-esteem in a sample of 377 adolescents and their mothers. Mothers' reports of family instability at Time 1 were significantly and positively associated with adolescent appraisals of family insecurity at Time 1 and Time 2. Adolescent self-esteem at Time 2 was significantly and negatively related to family instability at $\mathrm{T} 1$ and family insecurity at Time 1 and Time 2. Findings from structural equation models supported the hypothesis that family instability undermines adolescents' self-esteem one year later by directly threatening adolescents' appraisals of family as a safe and secure system. The results indicated that adolescent appraisals fully mediated the relation between family instability and adolescent self-esteem. The implications of the findings for adolescent development in a secure and stable family environment are discussed and suggestions for further process-oriented research on the relation between family instability and adolescent development are stated.

Keywords: family instability, security in the family system, self-esteem, adolescence

$\triangle \quad$ Marina Merkaš, Institute of Social Sciences Ivo Pilar, Marulićev trg 19/1, P. O. Box 277, 10001 Zagreb, Croatia. E-mail: Marina.Merkas@pilar.hr

The instability of family life has become an increasingly salient feature of children's lives over the past decade in different countries and this trend is also evident in Croatia. During this 
DRUŠ. ISTRAŽ. ZAGREB GOD. 23 (2014), BR. 1, STR. 47-66

MERKAŠ, M.: ADOLESCENT.. period, as is well-known, the economic crisis has left a significant mark on the socio-economic position of families, influencing children's lives. Due to financial strains on the family, children and their parents experience different unexpected transitions, such as changes in residence, housing, occupation and living standard. In addition, the structure of contemporary families is changing more rapidly now than ever before (i.e., the marriage rate is declining, the divorce rate is increasing, and cohabitation is becoming more frequent) (Brajša-Žganec et al., 2011). An increasing number of children experience different multiple transitions in family life that are not developmentally expected, and these transitions cause an instable family environment which poses a risk factor for children's development. The issue examined in this longitudinal study is how family instability can affect adolescent development directly as well as indirectly.

Family instability, as an important aspect of the quality of the home environment (Garrett, Ngandu, \& Ferron, 1994), "reflects disruptive events that undermine the continuity, cohesiveness, and predictability of family life from child's perspective" (Forman \& Davies, 2003, p. 94). In the present study, family instability is conceptualized as an aggregate of several kinds of events that challenge the everyday routine of family life for an adolescent (e.g., death in the family, parental job loss, changes in residence). Moreover, the intention was to capture the sources of disruption that primarily affect the functioning of the family as a whole. An interest in this study is not on acute stressors and recent negative stressful life events, which is a rather narrowed focus, but on events that may occur or co-occur repeatedly over the child's lifetime (Ackerman, Kogos, Youngstrom, Schoff, \& Izard, 1999). From an organizational perspective on development, adolescents' development is best understood if cumulative or simultaneous events co-occurring with a transitional period are explored concurrently (Cicchetti \& Rogosch, 2002). Previous research has shown that family instability is related to a variety of social and academic problems. For example, the number of marital transitions is linearly related to child (Capaldi \& Patterson, 1991) and adolescent psychological problems (e.g., antisocial behavior, substance use, peer rejection, self-esteem, depression, school grades) (Kurdek, Fine, \& Sinclair, 1995). As suggested by numerous studies, marital instability (e.g., parental divorce, marital discord and conflict, remarriage, changes in family structure) threaten children's and adolescents' well-being (Amato, 2006; Coleman, Ganong, \& Fine, 2000; Hetherington, 2006). In addition, the number of disruptive family events is related to internalizing and externalizing symptoms of young children 
DRUŠ. ISTRAŽ. ZAGREB GOD. 23 (2014), BR. 1 STR. 47-66

MERKAŠ, $M$. ADOLESCENT... living in economically disadvantaged families (Ackerman et al., 1999), and to internalizing and externalizing symptoms of early adolescents (Forman \& Davies, 2003).

Explanations why family instability poses a risk to children's and adolescents' adjustment have commonly focused on children's and adolescents' difficulties attaining the emotional security in the family unit and different dyadic family relationships in the face of repeated family disruptions (Ackerman et al., 1999; Forman \& Davies, 2003; Winter, Davies, \& Cummings, 2010). Emotional security theory (EST; Cummings \& Davies, 2011; Davies \& Cummings, 1994) postulates that preserving a sense of protection, security and safety is a central goal for children in the family setting. According to the EST and in line with the concept of working models and scripts in attachment and family system literature (Byng-Hall, 1999; Erdman \& Caffery, 2003), children's ability to preserve the goal of security is reflected in their internal representations of family experiences. Although primary emphasis in the EST is placed on understanding how children organize dyadic relations with attachment figures to preserve their sense of security in the face of marital instability, advances in the theory and the development of the family-wide model on the prepositions of family systems theory (e.g., Cummings \& Davies, 2011; Davies, Harold, Goeke-Morey, \& Cummings, 2002) provide possibility for broader assessment of children's representations of the whole family unit as a source of security, support, and threat (Forman \& Davies, 2005). Thus, this study will address the issue of adolescents' feelings of insecurity in their families as units or systems or adolescent appraisals of family insecurity.

Although internalizing and externalizing symptoms have been the primary outcomes examined in studies within the framework of EST, recent research has expanded the outcomes measures (e.g., romantic relationships, physical health, and substance use) (Cummings \& Davies, 2011). However, the self-esteem of early adolescents has not yet been considered. Self-esteem, as a person's appraisal of his or her worth or value, is based on the sense of acceptance or approval of significant others and the sense of personal efficacy or competence in a domain of importance (Brennan \& Bosson, 1998; Harter, 2003; Leary \& Baumeister, 2000). If adolescents are exposed to disruptive family events for a longer period of time, they are prone to developing insecure representations of their families. These representations are characterized by fears and worries about their own future in the family and the future of their families, emotional distancing from family members and a 
DRUŠ. ISTRAŽ. ZAGREB GOD. 23 (2014), BR. 1, STR. $47-66$

MERKAŠ, M.: ADOLESCENT.. lack of confidence in their families as a reliable source of support, security, stability and protection (Forman \& Davies, 2003). If adolescents feel that they cannot rely on their families for support and help, they can begin to feel neglected and ignored by their families and as a consequence develop appraisals of themselves as persons who are not worthy of care and support. Adolescents who develop these insecure representations may be especially likely to use their pessimistic expectancies as a guide in interpreting or understanding other novel interpersonal and social situations. Their tendency to respond in rigid, maladaptive ways in these situations may develop into forms of maladjustment that persist across time and settings (Davies et al., 2002). Further, adolescents can become involved in the protection and maintenance of the family system. If they do not succeed in preserving the integrity of the family system as well as their emotional security in the family system, they can begin to feel incompetent and powerless. This feeling of incompetence may lower adolescents' self-esteem. This is especially the case if adolescents see their incompetence as a general aspect of the self rather than specific reactions to events, which is likely to occur due to prolonged exposure to disruptive uncontrolled family events. In addition, resources and energy invested into preservation of emotional security may subsequently limit the resources adolescents need to pursue their developmental goals (Davies et al., 2002), among which is the development of self-esteem.

Despite the theoretical explanations linking family instability, children's appraisals of security in the family system, and child outcomes, little empirical evidence exist that support the hypothesis on the role of children's appraisals of security in the family system as a mediator in the relations between family instability and child outcomes. To the best of our knowledge, only one study examined and confirmed the mediation effect (Forman \& Davies, 2003) and only one study explored the relations between family instability, security in the family system and internalizing and externalizing symptoms in adolescents (Forman \& Davies, 2005). The present study was constructed to replicate and extend these findings in several ways. Firstly, the effects of family instability and security in the family system on adolescents' self-esteem are examined. Secondly, this study further refines the construct of family instability by examining and using two different, though related, indicators of family instability - the occurrence of negative events (the total number of disruptive events that happened in the family) and the overall incidence of negative events (the total number of times the family experienced each 
DRUŠ. ISTRAŽ. ZAGREB GOD. 23 (2014), BR. 1 STR. 47-66

MERKAŠ, $M$. ADOLESCENT...

\section{METHOD}

\section{Participants}

of the disruptive events). Finally, this study differs from previous studies in that it uses data collected from adolescents and their mothers at two points in time.

In summary, the aim of this two-wave study was to examine the mediating role of adolescent appraisals of family security in the relation between family instability and adolescent self-esteem. Based on the EST prepositions and the findings of previous studies, it is hypothesized that family instability threatens adolescents' sense of security in the family system by undermining the predictability, stability and continuity of family life, and thereby affects the adolescents' self-esteem.

Participants were 5th and 6th grade students from six primary schools located in the central and northwestern parts of Croatia and their mothers. They participated in a larger research project on social competence and family functioning involving two waves of data collection (Wave 1-2010, Wave 2-2011) (Merkaš, 2012). The sample comprised 377 adolescents (221 girls) ranging in age from 11 to 14 , with a mean of $12(\mathrm{SD}=$ 0.61 ), at the first wave of data collection (Time $1-\mathrm{T} 1$ ). Of the adolescents, $83 \%$ came from two-parent families, $16 \%$ came from single-parent families and $1 \%$ had been living with their legal guardians. A total of 377 mothers participated in the project. Mothers' mean age was 40.7 years $(S D=5.2)$. The majority of mothers $(62.5 \%$ ) had at least a high school diploma and they were employed (80.6\% of mothers). On a 5-point scale, the majority of mothers $(67.3 \%)$ rated the socio-economic standard of their family as average. Of the initial sample, $98 \%$ of adolescents and $66 \%$ of their mothers participated in the second wave of data collection (Time $2-\mathrm{T} 2$ ). The second measurement wave was 1 year apart from the first one. A logistic regression analysis was used to test whether sample attrition (dummy coded as dropout $=0$, and retention $=1$ ) can be predicted by the measured socio-demographic characteristic of the adolescent, mother and family at T1. The results of two regressions (samples of adolescents and their mothers) indicated that the attrition cannot be predicted on the basis of the measured socio-demographic characteristic of the adolescent, mother and their families $\left(\chi^{2}(9)=8.88, \mathrm{p}>0.01 ; \chi^{2}(10)=12.46, \mathrm{p}>0.01\right)$. Moreover, Little's test (1988) suggested that the data collected in the project were missing completely at random (MCAR), $\chi^{2}(8381)=7497.04, p>0.01$. 


\section{Family instability}

Family instability, which is defined as the degree to which families fail to provide continuity, cohesiveness, and stability for children, was measured using the adapted version of the Family Instability Questionnaire (Revised) (Forman \& Davies, 2003) and the Family Instability Index (Ackerman et al., 1999). The questionnaire consists of 13 items assessing the occurrence (no/yes) of disruptive life events in the family over the past five years (the occurrence of negative events) and the number of times the family experienced each of these disruptive events (the overall incidence of negative events). The disruptive events can conceptually be categorized into five family domains: a) changes in residence and housing conditions; b) job and income loss; c) death, serious illness and injury of a family member or close relatives/family friends; d) transitions in romantic relationships of primary caregivers (mother and father); e) quarrels with neighbors and relatives, and a physical assault on a family member. Mothers completed the questionnaire at T1. The negative life events predominantly concerned the death of close family friends or relatives $(40.1 \%)$, a serious illness of a family member $(41.8 \%)$, financial difficulties in the family $(30.4 \%)$, changes in residence $(30 \%)$ and mothers' and fathers' job loss (20.9\% and $17.1 \%)$. Less frequent events included quarrels with neighbors and relatives (16.4\%), a serious injury of a family member $(15 \%)$, a physical assault on a family member $(11.1 \%)$, divorce $(10.5 \%)$, changes to poor housing conditions $(9.8 \%$ ) and death in the family (death of a spouse or/and a child) $(4.2 \%)$.

The total number of different disruptive events (the occurrence) that happened in the family over the past five years was used as a main indicator of family instability in this study $(\mathrm{M}=2.45, \mathrm{SD}=2.01$, ranging from 0 to 10$)$, although in previous studies (Ackerman et al., 1999; Forman \& Davies, 2003, 2005) the number of times the family experienced the disruptive events (the overall incidence) was used (in this study descriptive statistics for the overall incidence are as follows $-\mathrm{M}=3.54$, $\mathrm{SD}=4.28$, ranging from 0 to 27 ). The decision to use the total number of events as the main indicator is based on the logic that it is easier to recollect whether the disruptive events had happened or not in the given time frame (five years) than to recollect exactly how many times each of them had happened - thus, it can be presumed that the total number of events is probably a more reliable and objective indicator of family instability. It is important to state that the correlation between these two indicators of family instability is $r=0.79, p<0.01$. However, all the results were reexamined using the overall 
DRUŠ. ISTRAŽ. ZAGREB GOD. 23 (2014), BR. 1 STR. 47-66

MERKAŠ, $M$ : ADOLESCENT.. incidence as an indicator of family instability. This was done to explore whether the results and the conclusions based on the results would change depending on the indicator used and to be able to compare the findings of this study with the previous studies that used only the incidence of events.

\section{Adolescent appraisals of family insecurity}

Adolescents completed the Security in the Family System scale (Forman \& Davies, 2005) at T1 and T2. This scale was translated into Croatian, the participants' native language. The 22-item scale measures the adolescent's perceived confidence in their families to serve as a base of protection, stability, and support. The instrument contains three interrelated scales of security (or insecurity) in the family as a whole. The 8-item Preoccupied scale assesses the adolescent's fears about the future well-being of themselves and their families (e.g., "Sometimes I feel that something very bad is going to happen in my family"). The 7-item Security (or Insecurity) scale assesses the adolescent's confidence in their family unit as a consistent resource of support and protection even during times of family trouble or stress (e.g., "I believe that family members will be around to help me in the future"). The 7-item Disengagement scale measures the adolescent's efforts to separate from and reduce the significance of the family in their lives (e.g., "When something bad happens in my family, I feel like running away"). Adolescents marked their agreement with the items on a 5-point scale (1-completely disagree, 5-completely agree). Because the scale was for the first time used among Croatian adolescents, the validity and reliability of the scale were explored. To assess the validity of the scale in the present sample, a confirmatory factor analysis (CFA) was performed on all the items at T1 and T2. In both waves a proposed three-factor solution showed a very good fit $\left(\mathrm{T} 1-\chi^{2}(206)=396.73, \mathrm{CFI}=0.92\right.$, RMSEA $=0.05$, SRMR $=0.05$; T2 $-\chi^{2}(206)=444.59, \mathrm{CFI}=0.92$, RMSEA $=0.06$, SRMR $=0.05$ ). The $\chi^{2} / \mathrm{df}$ ratio (values of 3 and less), the comparative fit index ( $\mathrm{CFI} \geq 0.90$ ), the root mean square error of approximation (RMSEA $\leq 0.06)$ and the standardized root mean squared residual (SRMR $\leq 0.08$ ) exceeded the standards of a good model fit (Hu \& Bentler, 1999; Kline, 2005; Schermelleh-Engel, Moosbrugger, \& Müller, 2003). All the items tapping the three dimensions (security, preoccupation, and dismissing) had significant loadings $(\geq 0.30)$ on their corresponding factors. Cronbach's alpha for the Security scale was 0.79 and 0.83 at T1 and T2, respectively. Cronbach's alpha for the Preoccupied scale was 0.81 and 0.85 at T1 and T2. Cronbach's alpha for the Disengagement scale was 0.73 and 0.80 at $\mathrm{T} 1$ and $\mathrm{T} 2$. The correlations between scales ranged from 0.30 to 0.58 at T1 and from 0.50 to 0.69 at T2. Stability 
DRUŠ. ISTRAŽ. ZAGREB GOD. 23 (2014), BR. 1, STR. 47-66

MERKAŠ, M.: ADOLESCENT..

\section{Procedure}

coefficients for scales ranged from 0.56 to 0.61 . All three scales were scored such that higher values indicate greater insecurity, and the results on the three scales were used as three indicators of the latent construct of adolescent appraisals of family insecurity.

\section{Self-esteem}

Adolescents rated their global self-esteem on the adapted and shortened version of the Coopersmith Self-Esteem Inventory (form B) (Coopersmith, 1967; Vulić-Prtorić, 2000) at T2. They rated 18 items (e.g., "There are a lot of things about myself I would change if I could") on a 5-point scale (1-completely disagree, 5-completely agree). This version of the Inventory was used among Croatian children, and showed good psychometric characteristics (Vulić-Prtorić, 2000). The reliability in the study was very good also (Cronbach's alpha was 0.91). All the items were recoded and summed into a total score, with higher scores reflecting higher self-esteem.

The dataset used in this paper is a part of the larger dataset collected in the research project on social competence and family functioning in Croatia (Merkaš, 2012). The consent for the conduction of the project in the schools was secured from the Ministry of Education, Science and Sport of the Republic of Croatia and the school principals. Three weeks prior to the student data collection (T1), all the students in the 5th and 6th grades in six conveniently selected primary schools were provided with a package for their parents (containing an instruction letter explaining the purpose of the project, an informed consent for parents' and child's participation in both waves of data collection, and a parent questionnaire). Students $(\mathrm{N}=979)$ were invited to deliver this package to their parents. In the instruction letter, parents were first asked to fill out the informed consent if they and their child wanted to participate in the research project, and then the parent questionnaire. Parents were asked to return their completed package in a sealed envelope to the child's homeroom teacher in a period of seven days. Of all the contacted parents, $39.5 \%$ of them signed the consent form and filled out the parent questionnaire. Student questionnaires were applied during regular school hours in the presence of the principal researcher of the project. Students had 45 minutes to complete the survey. The same procedure of data collection was applied at T2. Participation of students and their parents was voluntary (they could withdraw from the project whenever they wanted) and they did not receive any reward for their participation. Structured passwords were used for matching students' and parents' answers, and confidentiality was guaranteed. 


\section{RESULTS}

\section{Descriptive and correlation analyses}

Table 1 presents the means, standard deviations, and correlations between all the study variables. Univariate analyses of variance were performed with adolescents' gender as a between-subject variable and each of the study variables as dependent variables. No significant gender differences were found. On average, adolescents reported a moderate level of self-esteem and low insecurity in their families. The age of adolescents was not significantly related to any of the study variables. The correlations in Table 1 show that family instability at T1 (when indicated by the occurrence of disruptive events) is positively and significantly associated with all three scales measuring adolescent appraisals of family insecurity at T1. Mothers' report of family instability at T1 (when indicated by the occurrence of disruptive events) is significantly and positively associated with adolescents' reports of preoccupation and disengagement measured at T2. Adolescent self-esteem at $\mathrm{T} 2$ is negatively and significantly associated with their appraisals of family insecurity both at $\mathrm{T} 1$ and $\mathrm{T} 2$, and mothers'

Means, standard deviations, and correlations between study variables report of family instability at T1 (regardless of the used indicator).

\begin{tabular}{|c|c|c|c|c|c|c|c|c|c|c|}
\hline Variable & $\mathrm{M}$ & SD & 1 & 2 & 3 & 4 & 5 & 6 & 7 & 8 \\
\hline 1. Family instability (T1)a & 2.45 & 2.01 & - & & & & & & & \\
\hline 2. Family instability (T1) & 3.54 & 4.28 & $0.79^{* *}$ & - & & & & & & \\
\hline 3. SIFS - insecurity (T1) & 1.40 & 0.48 & $0.12^{*}$ & 0.09 & - & & & & & \\
\hline 4. SIFS - preoccupation (T1) & 2.15 & 0.73 & $0.23^{* *}$ & $0.19^{* *}$ & $0.30^{* *}$ & - & & & & \\
\hline 5. SIFS - disengagement (T1) & 1.71 & 0.63 & $0.17^{* *}$ & $0.14^{*}$ & $0.50^{* *}$ & $0.58^{* *}$ & - & & & \\
\hline 6. SIFS - insecurity (T2) & 1.51 & 0.55 & 0.07 & $0.16^{*}$ & $0.57^{* *}$ & $0.25^{* *}$ & $0.42^{* *}$ & - & & \\
\hline 7. SIFS - preoccupation (T2) & 2.10 & 0.76 & $0.18^{* *}$ & $0.24^{* *}$ & $0.30^{* *}$ & $0.61^{* *}$ & $0.46^{* *}$ & $0.49^{* *}$ & - & \\
\hline 8. SIFS - disengagement (T2) & 1.81 & 0.71 & $0.14^{*}$ & $0.17^{*}$ & $0.42^{* *}$ & $0.43^{* *}$ & $0.56^{* *}$ & $0.67^{* *}$ & $0.69^{* *}$ & - \\
\hline 9. Self-esteem (T2) & 3.90 & 0.74 & $-0.19^{* *}$ & $-0.22^{*}$ & $-0.32^{* *}$ & $-0.52^{* *}$ & $-0.48^{* *}$ & $-0.43^{* *}$ & $-0.65^{* *}$ & $-0.66^{* *}$ \\
\hline
\end{tabular}

Note. ${ }^{a}=$ Family instability indicated by the occurrence of disruptive negative events in the family. $\mathrm{b}=$ Family instability indicated by the number of times the family experienced each of the disruptive negative events (the incidence). SIFS = Security in the Family System scale; T1-Time 1; T2-Time 2. ${ }^{*} \mathrm{p}<0.05 .{ }^{* *} \mathrm{p}<0.01$.

\section{Primary analyses}

Structural equation modeling with latent variables was used to test the hypothesis in this study. Firstly, we examined the direct effect of family instability measured at $\mathrm{T} 1$ on adolescent self-esteem measured at T2. Secondly, we estimated the proposed mediation model, with adolescent appraisals of family insecurity as an intervening variable between family instability and self-esteem. Two models were tested since the design of the study allowed such an approach - in one model ado- 
DRUŠ. ISTRAŽ. ZAGREB GOD. 23 (2014), BR. 1, STR. 47-66

MERKAŠ, M.: ADOLESCENT.. lescent appraisals of family insecurity is measured at T1 (Figure $1 \mathrm{~A}$ ) and in the other at T2 (Figure 1B).

Adolescent appraisals of family insecurity and adolescent self-esteem were modeled as latent variables and family instability was represented as a manifested variable (the number of disruptive events or occurrence). The results on three scales (Security, Preoccupation, and Disengagement) of the Security in the Family System scale were used as three indicators of a latent variable entitled as adolescent appraisals of family insecurity. Adolescent self-esteem was represented by a set of four parcels containing items of the scale used to measure self-esteem. Parcels were constructed on the item-to-construct balance technique (Little, Cunningham, Shahar, \& Widaman, 2002). Although aggregating items into parcels has advantages as well as disadvantages (e.g., Little et al., 2002; Sass \& Smith, 2006), this technique was deemed appropriate as we wanted to model self-esteem as a latent construct, a single one-dimensional scale was used only for the measurement of self-esteem (the dimensionality of the scale was examined) and parcels were only used to build the measurement model.

Data screening of the indicator variables (i.e., the parcels, scale results) indicated that the assumptions of data normality were violated at the univariate level. Thus, in all the subsequent models, the asymptotic covariance matrix was used and the Satorra-Bentler scaled chi-square (SBS- $\chi^{2}$; Satorra \& Bentler, 1994) inspected to evaluate the model fit. To evaluate the model goodness of fit, we also selected the CFI, the RMSEA and the SRMR. The CFI $\geq 0.90$, the RMSEA $\leq 0.06$, and the SRMR $\leq 0.08$ indicate good model fit (Hu \& Bentler, 1999; Schermelleh-Engel et al., 2003). All models were estimated in Mplus 7 (Muthén \& Muthén, 1998-2012).

\section{Measurement models}

The measurement model with two latent variables and eight observed variables was tested. The two latent variables (self-esteem and family insecurity) and one manifested variable (family instability) were free to correlate in the model. Both the measurement model with adolescent appraisals of family insecurity at T1 and the measurement model with adolescent appraisals of family insecurity at $\mathrm{T} 2$ showed relatively good

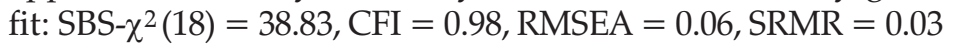
and SBS- $\chi^{2}(18)=56.27, \mathrm{CFI}=0.97, \mathrm{RMSEA}=0.08, \mathrm{SRMR}=0.04$. Allowing the correlated error between the two indicators of adolescent appraisals of family insecurity (the Security scale and the Dismissing scale) as indicated by the model modification indices, improved the fit of both measurement models: the model with adolescent appraisals at T1 $-\mathrm{SBS}-\chi^{2}(17)=23.33$ 
DRUŠ. ISTRAŽ. ZAGREB GOD. 23 (2014), BR. 1 STR. 47-66

MERKAŠ, $M$ : ADOLESCENT... (ns), CFI $=0.99$, RMSEA $=0.03$, SRMR $=0.02$, and the model with adolescent appraisals at $2-\mathrm{SBS}-\chi^{2}(17)=33.62, \mathrm{CFI}=0.99$, RMSEA $=0.05$, SRMR $=0.02$. Thus, these measurement models were used in the following analyses. Factor loadings of the indicators on their respective latent factors were moderate to high - ranging from 0.40 to 0.83 for adolescent appraisals of family insecurity and ranging from 0.85 to 0.90 for adolescent self-esteem - and significant $(\mathrm{p}<0.001)$. In sum, both measurement models provided a good representation of the data.

\section{Structural models}

We tested a set of structural models to investigate the main hypothesis of this study. In the first proposed structural model, mothers' reports of family instability at $\mathrm{T} 1$ predicts adolescent appraisals of family insecurity at T1, and adolescent appraisals of family insecurity at $\mathrm{T} 1$ predicts adolescent self-esteem at T2 (Figure 1A). In the second proposed structural model, mothers' reports of family instability at $\mathrm{T} 1$ predicts adolescent appraisals of family insecurity at $\mathrm{T} 2$, and adolescent appraisals of family insecurity at $\mathrm{T} 2$ predicts adolescent self-esteem at T2 (Figure 1B). Before testing these structural models, the direct effect of family instability on self-esteem was examined. In this model, mothers' reports of family instability at $\mathrm{T} 1$ was entered as a predictor of adolescent self-esteem at T2, and this link is the same in both proposed models. The results of the model, $\mathrm{SBS}^{2} \chi^{2}(5)=5.13(\mathrm{~ns}), \mathrm{CFI}=1.00, \mathrm{RMSEA}=0.01, \mathrm{SRMR}=0.01$, showed that mothers' reports of family instability at T1 was negatively related to adolescent self-esteem at $\mathrm{T} 2(\beta=-0.20$, $\mathrm{p}<0.001$ )

In the next set of models, we addressed the intervening role of adolescent appraisals of family insecurity in the relations between family instability and adolescent self-esteem. In the first model, family instability was only indirectly related to adolescent self-esteem through adolescent appraisals of family insecurity. Estimation of this model (without direct link between family instability and self-esteem) with adolescent appraisals of family insecurity at T1 yielded a good fit, SBS- $\chi^{2}(18)=14.51$ (ns), CFI $=1.00$, RMSEA $=0.00$, SRMR $=0.02$. The results showed that family instability at T1 was positively related to adolescent appraisals of family insecurity at $\mathrm{T} 1(\beta=0.28, \mathrm{p}<0.001)$, and that adolescent appraisals of family insecurity at $\mathrm{T} 1$ was negatively related to adolescent self-esteem at $\mathrm{T} 2(\beta=-0.69$, $p<0.001$ ). Estimation of the same kind of model (no direct link between family instability and self-esteem) with adolescent appraisals of family insecurity at $\mathrm{T} 2$ also showed a good fit, SBS- $\chi^{2}(18)=16.45(\mathrm{~ns}), \mathrm{CFI}=1.00, \mathrm{RMSEA}=0.00, \mathrm{SRMR}=0.02$ The results of this model showed that family instability at T1 
DRUŠ. ISTRAŽ. ZAGREB GOD. 23 (2014), BR. 1, STR. 47-66

MERKAŠ, M.: ADOLESCENT.. was positively related to adolescent appraisals of family insecurity at T2 $(\beta=0.21, \mathrm{p}<0.01)$, and that adolescent appraisals of family insecurity at T2 was negatively related to adolescent self-esteem at T2 $(\beta=-0.81, p<0.001)$. The results of the Sobel tests (1982) for indirect relations (for model with family insecurity at T1 $-\mathrm{z}=2.59, \mathrm{p}<0.01$; for model with family insecurity at $\mathrm{T} 2-\mathrm{z}=3.28, \mathrm{p}<0.01$ ) indicated that the indirect effect from family instability at T1 to self-esteem at T2 through adolescent appraisals of family insecurity at T1 as well as through adolescent appraisals of family insecurity at T2 were significant. A bootstrapped 95\% confidence interval (CI), obtained using resampling method (5000 bootstrap resamples) (Hayes, 2009; MacKinnon, Lockwood, Hoffman, West, \& Sheets, 2002; MacKinnon, Lockwood, \& Williams, 2004), around the indirect effect not containing zero (for model with family insecurity at $\mathrm{T} 1-\beta=-0.19, \mathrm{CI}=$ from -0.27 to -0.11 ; for model with family insecurity at $\mathrm{T} 2-\beta=-0.17, \mathrm{CI}=$ from -0.26 to -0.08$)$ confirmed the results of the Sobel tests.

Because family instability at T1 had a direct effect on adolescent self-esteem at T2, a second model (with direct link between family instability and self-esteem) was tested to examine whether this path would remain significant or would be significantly reduced after including adolescent appraisals of family insecurity as a mediator in the model. Adding a direct path from family instability at $\mathrm{T} 1$ to adolescent self-esteem at T2 did not improve the model fit significantly $\left(\Delta\right.$ SBS- $\chi^{2}(1)=0.22$, $\mathrm{p}>0.01$ ) (compared to model without direct link between instability and self-esteem described in the previous section), and this path was insignificant in the model with family insecurity at T1 (Figure 1A). Similarly, adding a direct path from family instability at $\mathrm{T} 1$ to adolescent self-esteem at T2 did not improved the model fit $\left(\Delta\right.$ SBS- $\left.\chi^{2}(1)=0.76, \mathrm{p}>0.01\right)$ (compared to model without direct link between instability and self-esteem described in the previous section), and this path was insignificant in the model with family insecurity at T2 (Figure 1B).

All the models and the results obtained in primary analyses were reexamined using the incidence of disruptive events (instead of the number of events or occurrence) as an indicator of family instability. This reexamination confirmed the previously described results and stated conclusions. Specifically, the results of the replication are similar to the primary results. Hence, it can be said that the relationships between family instability at $\mathrm{T} 1$ and adolescent self-esteem at $\mathrm{T} 2$ are fully mediated by adolescent appraisals of family insecurity at T1 in the first proposed model (Figure 1A), and by adolescent appraisals of family insecurity at $\mathrm{T} 2$ in the second proposed model (Figure 1B). 
$\rightarrow$ FIGURE 1A

Structural model of relationships between mothers' reports of family instability (T1) adolescent appraisals of family insecurity (T1), and adolescent self-esteem (T2)

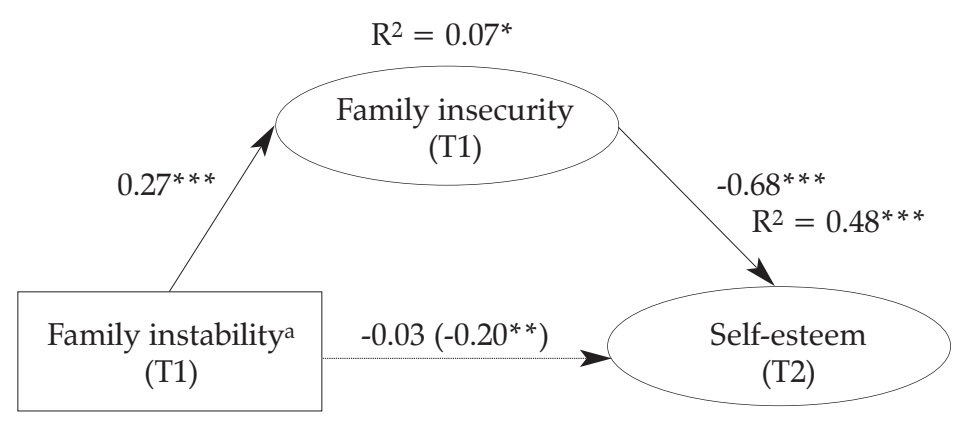

Coefficients are standardized path coefficients from a model with both direct and indirect link between family instability and self-esteem. A path coefficient in brackets is derived from the analysis of an unmediated model, in which only direct path from family instability to self-esteem was allowed. Model fit: SBS- $\chi^{2}(17)=14.15$ (ns), CFI = 1.00, $\mathrm{RMSEA}=0.00, \mathrm{SRMR}=0.02 . \mathrm{T} 1=$ Time $1 . \mathrm{T} 2=$ Time $2 . \mathrm{R}^{2}=$ amount of variance explained in the latent constructs at T1 and T2. a = Family instability indicated by the occurrence of disruptive negative events in the family. ${ }^{*} \mathrm{p}<0.05 .{ }^{* *} \mathrm{p}<0.01{ }^{* * *} \mathrm{p}<0.001$.

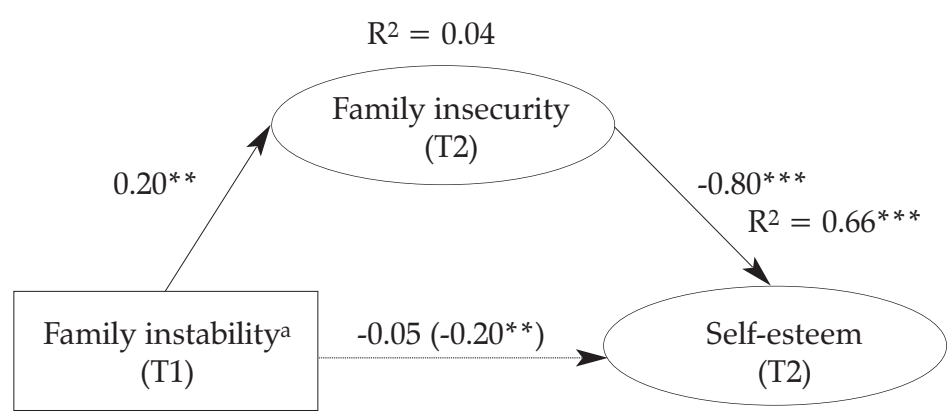

Coefficients are standardized path coefficients from a model with both direct and indirect link between family instability and self-esteem. A path coefficient in brackets is derived from the analysis of an unmediated model, in which only direct path from family instability to self-esteem was allowed. Model fit: SBS- $\chi^{2}(17)=15.67$ (ns), CFI = 1.00, RMSEA $=0.00$, SRMR $=0.02 . \mathrm{T} 1=$ Time $1 . \mathrm{T} 2=$ Time $2 . \mathrm{R}^{2}=$ amount of variance explained in the latent constructs at T2. $\mathrm{a}=$ Family instability indicated by the occurrence of disruptive negative events in the family. ${ }^{*} \mathrm{p}<0.05 .{ }^{* *} \mathrm{p}<0.01 .{ }^{* * *} \mathrm{p}<0.001$

The main aim of this study was to provide further support for the hypothesis that adolescent appraisals of family security is a mediator variable in the relation between family instability and adolescents' adjustment. The results of the study supported the proposed hypothesis about the mediation effect of adolescent appraisals of family security which is based on the 
DRUŠ. ISTRAŽ. ZAGREB GOD. 23 (2014), BR. 1, STR. 47-66

MERKAŠ, M.: ADOLESCENT..
EST (Cummings \& Davies, 2011), and suggest that adolescent appraisals of family security fully mediate the relation between family instability and adolescent self-esteem. Long-term family instability characterized by numerous different as well as frequent disruptive events in the family undermines the adolescent perception of the family as a safe and secure system for development, and thereby negatively affects adolescent feelings of self-worth. So, adolescents exposed to very high instability were more likely to interpret disruptive events as having negative consequences for their family's well-being and for their self-esteem. This conclusion is strengthened because it is based on data collected at two time points, mothers' and adolescents' reports and it is robust regardless of the used indicator of family instability. The findings point to the importance of a stable, secure and reliable family environment for adolescent development.

According to the family-wide conceptualization of emotional security (Cummings \& Davies, 1996; Davies et al., 2002) and advances in the EST (Cummings \& Davies, 2011), cumulative and frequent experiences with unstable family environment due to disruptive events directly affect adolescent adjustment and development by diminishing adolescents' perception of the family as a source of security and support. The results of this study support this hypothesis and are consistent with previous empirical findings (Forman \& Davies, 2003). The results further indicate that adolescents' self-esteem decreases as a function of the number of disruptive family events which when taken all together, we could argue, form a composite risk score for adolescent self-esteem (Masten \& Shaffer, 2006). In addition, these findings correspond to the previous findings (Forman \& Davies, 2003) in that family instability is a proximal and not a distal marker for adolescent development, although family instability can affect other family characteristics and thereby affect adolescent development. Related to this, and in addressing the chain of mediation between family instability and adolescent adjustment, it is important to state that other processes and mechanisms exist that can also act as mediators. Thus, adolescent appraisal of family security is probably not the only mechanism by which family instability can undermine adolescent self-esteem. Different characteristics of adolescents (e.g., personality traits, temperament), their parents (e.g., personality traits, parenting practice) and families (e.g., quality of family relations, satisfaction with the family, family functioning) can act as mediators (or intervening variables) in the relation between family instability and adolescent self-esteem. Moreover, different characteristics of adolescents (e.g., gender, age, emotional regulation), their parents (e.g., emotional regulation) and fami- 
DRUŠ. ISTRAŽ. ZAGREB GOD. 23 (2014), BR. 1 STR. 47-66

MERKAŠ, $M$. ADOLESCENT.. lies (e.g., family functioning) can moderate (weakening or strengthening) the relation between family instability and adolescent self-esteem. These are all potential mediators and/or moderators which further studies, especially longitudinal ones using multitrait-multimethod approach, should take into account when developing the model of effects of family instability on adolescent self-esteem. In addition, including different measures of adolescents' appraisals, coping, and affect from other theoretical frameworks (e.g., Grych \& Fincham, 1990) will likely expose that multiple internal process in adolescents' account for the relation between instability and self-esteem.

Different explanations based on different theoretical models and frameworks can be offered on why adolescent appraisal of family insecurity mediates the relation between family instability and adolescent self-esteem. At this point two explanations may be offered, taking into account two determinants of self-esteem - acceptance and competence. It is possible that disruptive family events contribute to the development of insecure representation of the family and that these insecure representations lay the foundation for a decline in self-esteem. Adolescents who feel that their families will not be a safe haven and a safe base for them may start to think about themselves as persons who do not deserve protection, care and love. This may negatively reflect on adolescents' self-esteem since one of the sources of high self-esteem include acceptance, positive appraisals, care and support from significant others. Related to this is the assumption about parental difficulties in providing a secure, stable, and supportive family environment for adolescent development due to family instability (Ackerman et al., 1990; Bowlby, 1969; Cummings \& Davies, 2002). In addition, if parents are under greater stress due to heightened family instability which is not under their control, they can start to feel depressed, anxious and helpless, which may negatively affect their parenting and relationships with adolescents (Forman \& Davies, 2003). Adolescents who are constantly exposed to this kind of unstable and insecure family environment may start to feel that they do not deserve support, security and stability in the family home. Consequently, they may start to think about themselves as persons who are not worthy of affection, support and love, and this is likely to be reflected in their lower self-esteem. Further, if adolescents perceive that their family life and environment is threatened, they may try to interfere as to preserve the stability and security of family life. If they do not succeed in preserving their emotional security in the family, they may start to feel incompetent and powerless. This sense of incompetence may diminish their self-esteem, especially if they integrate this sense of incompetence in their self-concept. Related 
DRUŠ. ISTRAŽ. ZAGREB GOD. 23 (2014), BR. 1, STR. $47-66$

MERKAŠ, M.: ADOLESCENT.. to this, adolescents need to invest time and energy to preserve family integrity, which reduces the resources they have for dealing with important developmental goals, including the development of positive self-concept (Davies et al., 2002). Overall, the problem is that these insecure representations or appraisals may serve as blueprints for future insecurities in novel social and interpersonal situations (Davies et al., 2002). Further research should shed a light on these assumptions and provide empirical support for the given explanations.

It is important to note the limitations of the findings from this study. Although this study comprised two waves of data collection, this is still not sufficient to conclude that the proposed mediation chain is accurate. One limitation inherent to the research design used in the study is that it does not enable us to discard different alternative explanations of the correlation pattern found in the results. The non-experimental design used in the study can only provide supporting but not decisive evidence that the mediation process is true, accurate and the only possible explanation of the link between disruptive family events and adolescents' self-esteem. Further research should include comprehensive longitudinal designs using at least three waves of data collection with constructs being measured at each wave and examining different models and mediation chains between constructs. This study encompasses a relatively homogeneous sample of families, and further studies should include more heterogeneous samples, especially with regard to education of parents and living standard. Moreover, focus on positive indicators of development and different outcomes measures should be introduced. Similarly, the measures of family instability should be further developed. There are not many instruments available for the examination of stressful family events in the literature, especially at the levels of family as a unit (Buehler, 1990). The intensity of the stress related to each disruptive event could be examined in adolescents and parents in the future. Maybe this could provide us with a more thorough understanding of how different negative and disruptive events are perceived by different family members and how threatening they are for them and their families. Related to this, the Double ABCX Model of family stress and adaptation (Lavee, McCubbin, \& Patterson, 1985) could be included in research on the effects of family instability on adolescent development. Finally, further studies in this area should continue to investigate the developmental period of early adolescence because co-occurrence of puberty with unexpected family transitions and negative events can be very challenging for adolescents.

Despite these limitations, this study contributes to the process-oriented research on the effects of family instability on adolescent development and provides an empirical sup- 
DRUŠ. ISTRAŽ. ZAGREB GOD. 23 (2014), BR. 1 STR. 47-66

MERKAŠ, M.: ADOLESCENT.. port to the EST. Although the effects are small in magnitude, they demonstrate the significance of disruptive events in the family for long-term adjustment and development of adolescents. The results imply that long-term and frequent exposure to family instability poses a risk for the development of the adolescents' feeling of self-worth by affecting the way adolescents perceive their families as sources of both security and threat.

\section{REFERENCES}

Ackerman, B. P., Kogos, J., Youngstrom, E., Schoff, K., \& Izard, C. (1999). Family instability and the problem behaviors of children from economically disadvantaged families. Developmental Psychology, 35(1), 258-268. http://dx.doi.org/10.1037//0012-1649.35.1.258

Amato, P. (2006). Marital discord, divorce, and children's well-being. In A. Clarke-Stewart, \& J. Dunn (Eds.), Families count: Effects on child and adolescent development (pp. 179-202). New York: Cambridge University Press. http://dx.doi.org/10.1017/CBO9780511616259.009

Bowlby, J. (1969). Attachment and loss (Vol. 1). New York, Basic Books.

Brajša-Žganec, A., Franc, R., Merkaš, M., Radačić, I., Šerić, I., \& Šikić-Mićanović, L. (2011). Situation analysis of children's and women's rights in Croatia. Zagreb: UNICEF Office for Croatia.

Brennan, K. A., \& Bosson, J. K. (1998). Attachment-style differences in attitudes toward and reactions to feedback from romantic partners: An exploration of the relational bases of self-esteem. Personality and Social Psychology Bulletin, 24(7), 699-714. http://dx.doi.org/10.1177/ 0146167298247003

Buehler, C. (1990). Adjustment. In J. Touliatos, B. F. Permutter, \& M. A. Straus (Eds.), Handbook of family measurement techniques (pp. 493-516). Newbury Park: SAGE Publications, Inc.

Byng-Hall, J. (1999). Family and couple therapy: Toward greater security. In J. Cassidy, \& P. R. Shaver (Eds.), Handbook of attachment: Theory, research, and clinical applications (pp. 625-670). New York: The Guilford Press.

Capaldi, D. M., \& Patterson, G. R. (1991). Relation of parental transitions to boys' adjustment problems: I. A linear hypothesis. II. Mothers at risk for transitions and unskilled parenting. Developmental Psychology, 27(3), 489-504. http://dx.doi.org/10.1037/0012-1649.27.3.489 Cicchetti, D., \& Rogosch, F. A. (2002). A developmental psychopathology perspective on adolescence. Journal of Consulting and Clinical Psychology, 70(1), 6-20. http://dx.doi.org/10.1037//0022-006X.70.1.6

Coleman, M., Ganong, L., \& Fine, M. (2000). Reinvestigating remarriage: Another decade of progress. Journal of Marriage and Family, 62(4), 1288-1307. http://dx.doi.org/10.1111/j.1741-3737.2000.01288.x

Coopersmith, S. (1967). The antecedents of self-esteem. San Francisco: W. H. Freeman and Co.

Cummings, E. M., \& Davies, P. T. (1996). Emotional security as a regulatory process in normal development and the development of psychopathology. Development and Psychopathology, 8(1), 123-139. http://dx. doi.org/10.1017/S0954579400007008 
DRUŠ. ISTRAŽ. ZAGREB GOD. 23 (2014), BR. 1, STR. $47-66$

MERKAŠ, M.: ADOLESCENT..
Cummings, E. M., \& Davies, P. T. (2002). Effects of marital conflict on children: Recent advances and emerging themes in process-oriented research. Journal of Child Psychology and Psychiatry, 43(1), 31-63. http://dx.doi.org/10.1111/1469-7610.00003

Cummings, E. M., \& Davies, P. T. (2011). Marital conflict and children: An emotional security perspective. New York and London: The Guilford Press.

Davies, P. T., \& Cummings, E. M. (1994). Marital conflict and child adjustment: An emotional security hypothesis. Psychological Bulletin, 116(3), 387-411. http://dx.doi.org/10.1037/0033-2909.116.3.387

Davies, P. T., Harold, G. T., Goeke-Morey, M. C., \& Cummings, E. M. (2002). Children's emotional security and interparental conflict. Monographs of the Society for Research on Child Development, 67 (3; Serial No. 270), 131 pages.

Erdman, P., \& Caffery, T. (Eds.) (2003). Attachment and family systems: Conceptual, empirical, and therapeutic relatedness. New York: Brunner-Routledge.

Forman, E. M., \& Davies, P. T. (2003). Family instability and adolescent adjustment: The mediating effects of parenting quality and adolescent appraisals of family security. Journal of Clinical Child and Adolescent Psychology, 32(1), 94-105. http://dx.doi.org/10.1207/S15374424JCC P3201_09

Forman, E. M., \& Davies, P. T. (2005). Assessing children's appraisals of security in the family system: The development of the Security in the Family System (SIFS) scales. Journal of Child Psychology and Psychiatry, 46(8), 900-916. http://dx.doi.org/10.1111/j.1469-7610.2004.00385.x

Garrett, P., Ngandu, N., \& Ferron, J. (1994). Poverty experiences of young children and the quality of their home environments. Child Development, 65(2), 331-345. http://dx.doi.org/10.1111/j.1467-8624.1994. tb00754.x

Grych, J. H., \& Fincham, F. D. (1990). Marital conflict and children's adjustment: A cognitive-contextual framework. Psychological Bulletin, 108(2), 267-290. http://dx.doi.org/10.1037/0033-2909.108.2.267

Harter, S. (2003). The development of self-representations during childhood and adolescence. In M. R. Leary, \& J. P. Tangney (Eds.), Handbook of self and identity (pp. 610-642). New York: The Guilford Press.

Hayes, A. F. (2009). Beyond Baron and Kenny: Statistical mediation analysis in the new millennium. Communication Monographs, 76(4), 408-420. http://dx.doi.org/10.1080/03637750903310360

Hetherington, E. M. (2006). The influence of conflict, marital problem solving and parenting on children's adjustment in nondivorced, divorced and remarried families. In A. Clarke-Stewart, \& J. Dunn (Eds.), Families count: Effects on child and adolescent development (pp. 203-237). New York: Cambridge University Press. http://dx.doi.org/10.1017/ CBO9780511616259.010

Hu, L. T., \& Bentler, P. M. (1999). Cutoff criteria for fit indexes in covariance structure analysis: Conventional criteria versus new alternatives. Structural Equation Modeling, 6(1), 1-55. http://dx.doi.org/10. 1080/10705519909540118 
DRUŠ. ISTRAŽ. ZAGREB GOD. 23 (2014), BR. 1 STR. 47-66

MERKAŠ, M.: ADOLESCENT...
Kline, R. B. (2005). Principles and practice of structural equation modeling (2nd Edition). New York: The Guilford Press.

Kurdek, L. A., Fine, M. A., \& Sinclair, R. J. (1995). School adjustment in sixth graders: Parenting transitions, family climate, and peer norm. Child Development, 66(2), 430-445. http://dx.doi.org/10.1111/j.1467-8624. 1995.tb00881.x

Lavee, Y., McCubbin, H. I., \& Patterson, J. (1985). The Double ABCX Model of family stress and adaptation: An empirical test by analysis of structural equations with latent variables. Journal of Marriage and the Family, 47(4), 811-825. http://dx.doi.org/10.2307/352326

Leary, M. R., \& Baumeister, R. F. (2000). The nature and function of self-esteem: Sociometer theory. In M. P. Zanna (Ed.), Advances in experimental social psychology (Vol. 32, pp. 1-62). San Diego: Academic Press.

Little, R. J. A. (1988). A test of missing completely at random for multivariate data with missing values. Journal of the American Statistical Association, 83(404), 1198-1202. http://dx.doi.org/10.1080/01621459.1988. 10478722

Little, T. D., Cunningham, W. A., Shahar, G., \& Widaman, K. F. (2002). To parcel or not to parcel: Exploring the question and weighing the merits. Structural Equation Modeling, 9(2), 151-173. http://dx.doi.org/ 10.1207/S15328007SEM0902 1

MacKinnon, D. P., Lockwood, C. M., Hoffman, J. M., West, S. G., \& Sheets, V. (2002). A comparison of methods to test mediation and other intervening variable effects. Psychological Methods, 7(1), 83-104. http://dx.doi.org/10.1037/1082-989X.7.1.83

MacKinnon, D. P., Lockwood, C. M., \& Williams, J. (2004). Confidence limits for the indirect effect: Distribution of the product and resampling methods. Multivariate Behavioral Research, 39(1), 99-128. http://dx.doi.org/10.1207/s15327906mbr3901_4

Masten, A. S., \& Shaffer, A. (2006). How families matter in child development: Reflections from research on risk and resilience. In A. Clarke-Stewart, \& J. Dunn (Eds.), Families count: Effects on child and adolescent development (pp. 5-25). New York: Cambridge University Press. http://dx.doi.org/10.1017/CBO9780511616259.002

Merkaš, M. (2012). Uloga obitelji u razvoju socijalne kompetencije adolescenata [The role of the family in development of adolescent social competence]. (Unpublished doctoral dissertation). University of Zagreb, Zagreb.

Muthén, L. K., \& Muthén, B. O. (1998-2012). Mplus User's Guide. Seventh Edition. Los Angeles, California: Muthén and Muthén.

Sass, D. A., \& Smith, P. L. (2006). The effects of parceling unidimensional scales on structural parameter estimates in structural equation modeling. Structural Equation Modeling, 13(4), 566-586. http://dx.doi. org/10.1207/s15328007sem1304_4

Satorra, A., \& Bentler, P. M. (1994). Corrections to test statistics and standard errors in covariance structure analysis. In A. von Eye, \& C. C. Clogg (Eds.), Latent variable analysis: Applications to developmental research (pp. 399-419). Thousand Oaks: California, SAGE Publications, Inc. 
DRUŠ. ISTRAŽ. ZAGREB GOD. 23 (2014), BR. 1, STR. $47-66$

MERKAŠ, M.: ADOLESCENT..
Schermelleh-Engel, K., Moosbrugger, H., \& Müller, H. (2003). Evaluating the fit of structural equation models: Test of significance and descriptive goodness-of-fit measures. Methods of Psychological Research Online, 8(2), 23-74. Available at http://www.cob.unt.edu/slides/paswan/ busi6280/Y-Muller_Erfurt_2003.pdf

Sobel, M. E. (1982). Asymptotic confidence intervals for indirect effects in structural equation models. In S. Leinhardt (Ed.), Sociological methodology (pp. 290-212). San Francisco: Jossey-Boss.

Vulić-Prtorić A. (2000). Struktura anksioznosti i depresionosti u djece i adolescenata: Provjera hijerarhijskog modela [Structure of anxiety and depression among children: Examination of hierarchical model]. (Unpublished doctoral dissertation). University of Zagreb, Zagreb.

Winter, M. A., Davies, P. T., \& Cummings, E. M. (2010). Children's security in the context of family instability and maternal communications. Merrill Palmer Quarterly, 56(2), 131-142. http://dx.doi.org/10.1353/mpq.0.0043

\section{Procjene adolescenta o sigurnosti u obiteli kao medijator učinka obiteljske nestabilnosti na samopoštovanje adolescenta}

Marina MERKAŠ

Institut društvenih znanosti Ivo Pilar, Zagreb

Cilj ovog istraživanja, koje je temeljeno na podatcima prikupljenima u dvije vremenske točke, bio je ispitati medijacijsku ulogu samoprocjene sigurnosti adolescenta $u$ obitelj u odnosu između obiteljske nestabilnosti i samopoštovanja adolescenata na uzorku od 377 adolescenata i njihovih majki. Majčine procjene obiteljske nestabilnosti u prvoj vremenskoj točki bile su značajno pozitivno povezane s adolescentovim procjenama nesigurnosti u obitelj u prvoj i drugoj vremenskoj točki. Adolescentovo samopoštovanje u drugoj vremenskoj točki značajno je negativno povezano s obiteljskom nestabilnosti u prvoj vremenskoj točki i nesigurnosti u obitelii u prvoj i drugoj vremenskoj točki. Nalazi testiranja modela strukturalnih jednadžbi dali su potvrdu postavljene hipoteze - obiteljska nestabilnost umanjuje adolescentovo samopoštovanje nakon godine dana, izravno ugrožavajući percepciju adolescenta o obitelii kao sigurnom i zaštićujućem sustavu. Rezultati pokazuju da procjene adolescenta potpuno posreduju u odnosu obiteliske nestabilnosti i adolescentskoga samopoštovanja. U radu su raspravljene implikacije nalaza za adolescentski razvoj u sigurnoj i stabilnoj obiteljskoj okolini i iznesene su sugestije za buduća procesno orijentirana istraživanja odnosa obiteljske nestabilnosti i adolescentskog razvoja.

Ključne riječi: obiteljska nestabilnost, sigurnost u obiteljski sustav, samopoštovanje, adolescencija 